\title{
Identification and full-genome sequencing of canine kobuvirus in canine fecal samples collected from Anhui Province, eastern China
}

\author{
Yong Wang ${ }^{1}$ (D) Yongqiu Cui ${ }^{1}$. Yeqiu $\mathrm{Li}^{1} \cdot$ Xiaopeng Wang $^{1} \cdot$ Kankan Yang $^{1} \cdot$ Da Zhang $^{1} \cdot$ Liang Zhao $^{1} \cdot$ Caixia Bai $^{1}$. \\ Shudong Jiang ${ }^{1} \cdot$ Yongdong $\mathrm{Li}^{2}$
}

Received: 9 January 2020 / Accepted: 9 July 2020 / Published online: 9 August 2020

(c) Springer-Verlag GmbH Austria, part of Springer Nature 2020

\begin{abstract}
Canine kobuvirus (CaKoV), a newly described virus, is the causative agent of gastroenteritis in dogs. In this study, 57 fecal samples from dogs with diarrhea in Anhui Province, eastern China, were collected. Among these, five samples were identified to be infected with $\mathrm{CaKoV}$, by polymerase chain reaction targeting the $\mathrm{CaKoV} 3 D$ gene. The five $\mathrm{CaKoV}$ strains were subjected to phylogenetic analysis. The sequences of $V P 1$ from the five $\mathrm{CaKoV}$ strains were 93.6\%-96.1\% identical to each other and $91.75 \%-97.95 \%$ identical to other reported CaKoV VP1 sequences. In addition, the complete genome of one strain was successfully amplified and sequenced. The genome consisted of 8223 nucleotides and shared $94.6 \%-97.0 \%$ nucleotide and $93.1 \%-94.0 \%$ amino acid sequence identity with other $\mathrm{CaKoV}$ isolates. Phylogenetic analysis revealed that the CaKoV strain from Anhui Province was similar to other Chinese strains, and it was more closely related to feline and mouse kobuviruses than to sheep and bovine kobuviruses. Interestingly, all of the $\mathrm{CaKoV}$-positive samples were coinfected with canine parvovirus. The finding of $\mathrm{CaKoV}$ infection in dogs with diarrhea and coinfection with canine parvovirus are a cause for concern and highlight the need for management and preventive measures.
\end{abstract}

\section{Introduction}

Kobuvirus, a genus of the family Picornaviridae, is divided into six species, namely Aichivirus $A$ (human kobuvirus), Aichivirus $B$ (bovine kobuvirus), Aichivirus $C$ (porcine kobuvirus), Aichivirus $D$ (kagovirus 1), Aichivirus $E$ (rabbit picornavirus), and Aichivirus $F$ (bat kobuvirus) [3, 16, 20, 21]. Canine kobuvirus $(\mathrm{CaKoV})$ is a member of the species

Handling Editor: Tim Skern.

Yong Wang and Yongqiu Cui contributed equally to this work and considered to be the co-first authors.

Shudong Jiang

jshudong@163.com

$\triangle$ Yongdong Li

liyd0551@126.com

1 Anhui Province Key Laboratory of Veterinary Pathobiology and Disease Control, College of Animal Science and Technology, Anhui Agricultural University, Hefei 230036, People's Republic of China

2 Municipal Key Laboratory of Virology, Ningbo Municipal Center for Disease Control and Prevention, Ningbo 315010, China
Aichivirus A [1,9]. In 2011, the whole genome sequence of a CaKoV isolate was first determined in the United States of America [9]. Thereafter, the complete genomes of CaKoV isolates have been sequenced in various countries, including China, Britain, Italy, South Korea, Tanzania, Kenya, and Japan $[2,6,7,10,14,19]$. The CaKoV genome is $8.1-8.2 \mathrm{~kb}$ long, with one open reading frame (ORF) and a 5' untranslated region (UTR). The ORF contains 7332-7341 nucleotides (nt) that encode a polyprotein of 2442-2475 amino acids (aa) [11]. The ORF encodes a leader (L) protein, three structural proteins (VP0, VP3, and VP1), and seven nonstructural proteins (2A, 2B, 2C, 3A, 3B, 3C, and 3D), and this is followed by a 3'-UTR and a poly(A) tail. The structural proteins form the capsid, which is associated with the adsorption and entry of virus particles into cells. Based on the sequence of the VPl gene, virus strains can be divided into two groups [12]. The non-structural proteins and intermediates are involved in RNA replication, polyprotein cleavage, and virion assembly [9].

$\mathrm{CaKoV}$ is frequently detected in dogs with diarrhea but is also associated with asymptomatic infections $[4,8,18]$. This virus has also been detected in wild carnivores such as jackals, foxes, and hyenas $[8,14]$. The virus is found not only in the digestive system but also in the cerebellum, lungs, 
tonsils, and liver, indicating that $\mathrm{CaKoV}$ might cause serious systemic infections [18].

Although the complete genomes of $\mathrm{CaKoV}$ isolates from several countries have been sequenced, studies on the characterization of endemic $\mathrm{CaKoV}$ strains in mainland China are limited. CaKoV infections have been reported in northeast and southwest China [10, 12]. However, there is a lack of genetic data on circulating $\mathrm{CaKoV}$ strains in eastern China. In the present study, CaKoV strains were detected in dogs with diarrhea from Anhui Province, eastern China, and the complete genome of one strain was successfully sequenced. Based on phylogenetic analysis, the prevalence of these $\mathrm{CaKoV}$ strains was analyzed, and the genetic diversity of $\mathrm{CaKoV}$ was investigated by comparing complete genome and $V P 1$ gene sequences with those of $\mathrm{CaKoV}$ reference strains. To the best of our knowledge, this is the first phylogenetic analysis of $\mathrm{CaKoV}$ strains isolated from Anhui Province. The results can help to better understand the epidemiology of $\mathrm{CaKoV}$ in eastern China.

\section{Materials and methods}

\section{Sample collection}

Fecal samples were collected from dogs with diarrhea in several animal hospitals in Hefei, Ma'anshan, Anhui Province from January 2018 to July 2019. All fecal samples were stored at $-80^{\circ} \mathrm{C}$ until further analysis.

\section{RNA extraction and cDNA synthesis}

The fecal samples were resuspended in phosphate-buffered saline at approximately $0.1-0.2 \mathrm{~g} / \mathrm{ml}$ by vortexing and then centrifuged at $12,000 \mathrm{~g}$ for $10 \mathrm{~min}$. The suspension was then collected in a new centrifuge tube without RNase. Viral RNA was extracted using a TIANamp Virus DNA/RNA Kit (Tiangen Biotech Co., Ltd., China) according to the manufacturer's instructions [10]. The extracted RNA was reverse transcribed into cDNA using a PrimeScript ${ }^{\mathrm{TM}}$ First Strand cDNA Synthesis Kit (TaKaRa BIO INC, Japan) according to the manufacturer's instructions [12]. The cDNA was stored at $-20{ }^{\circ} \mathrm{C}$ until further analysis.

\section{CaKoV detection in samples}

Real-time polymerase chain reaction (RT-PCR) was conducted by targeting the $\mathrm{CaKoV} 3 D$ gene [7]. The specific primers used for RT-PCR are listed in Table 1. The predicted size of the PCR product was $504 \mathrm{bp}$. The amplified product was purified and cloned into the pMD-19T vector (TaKaRa). The recombinant plasmid was then sequenced by Sangon Company.

\section{Screening for coinfection with canine enteric pathogens}

All CaKoV-positive samples were examined for the presence of canine enteric pathogens. The samples were tested for canine parvovirus (CPV, GenBank accession

Table 1 Specific primers used for detection of $\mathrm{CaKoV}$ and other enteroviruses

\begin{tabular}{|c|c|c|c|c|}
\hline Primer name & $\begin{array}{l}\text { Nucleotide sequence } \\
\left(5^{\prime}-3^{\prime}\right)\end{array}$ & $\begin{array}{l}\text { Target } \\
\text { gene }\end{array}$ & $\begin{array}{l}\text { Amplicon size } \\
\text { (bp) }\end{array}$ & Reaction conditions \\
\hline $\begin{array}{l}\text { CaKoV-3D-F } \\
\text { CaKoV-3D-R }\end{array}$ & $\begin{array}{l}\text { CCCTGGAACACCCAAGGCCGCT } \\
\text { TCTGGTTGCCATAGATGTGGTG }\end{array}$ & $3 \mathrm{D}$ & 504 & $\begin{array}{l}94^{\circ} \mathrm{C} \text { for } 2 \mathrm{~min} \text {, followed by } 40 \text { cycles at } 94^{\circ} \mathrm{C} \text { for } 45 \mathrm{~s} \text {, } \\
48^{\circ} \mathrm{C} \text { for } 1 \mathrm{~min} \text { and } 72^{\circ} \mathrm{C} \text { for } 50 \mathrm{~s} \text { and a final exten- } \\
\text { sion step at } 72^{\circ} \mathrm{C} \text { for } 10 \mathrm{~min}\end{array}$ \\
\hline $\begin{array}{l}\text { CaKoV-VP1-F } \\
\text { CaKoV-VP1-R }\end{array}$ & $\begin{array}{l}\text { GCGAACTCAGAAGATCTCAATGCGC } \\
\text { ATAGGTGGGCCTATCTGCACGGACG }\end{array}$ & VP1 & 834 & $\begin{array}{l}95^{\circ} \mathrm{C} \text { for } 5 \mathrm{~min} \text {, followed by } 30 \text { cycles at } 95^{\circ} \mathrm{C} \text { for } 30 \mathrm{~s} \text {, } \\
57^{\circ} \mathrm{C} \text { for } 30 \mathrm{~s} \text { and } 72^{\circ} \mathrm{C} \text { for } 1 \text { min and a final exten- } \\
\text { sion step at } 72^{\circ} \mathrm{C} \text { for } 10 \mathrm{~min}\end{array}$ \\
\hline $\begin{array}{l}\text { CPV-F } \\
\text { CPV-R }\end{array}$ & $\begin{array}{l}\text { GGGGATTTCTACGGGTACTTT } \\
\text { TGGTAAGCCCAATGCTCTAT }\end{array}$ & VP2 & 751 & $\begin{array}{l}95^{\circ} \mathrm{C} \text { for } 5 \mathrm{~min} \text {, followed by } 30 \mathrm{cycles} \text { at } 95^{\circ} \mathrm{C} \text { for } 30 \mathrm{~s} \text {, } \\
50^{\circ} \mathrm{C} \text { for } 30 \mathrm{~s} \text { and } 72^{\circ} \mathrm{C} \text { for } 50 \mathrm{~s} \text { and a final extension } \\
\text { step at } 72^{\circ} \mathrm{C} \text { for } 10 \mathrm{~min}\end{array}$ \\
\hline $\begin{array}{l}\text { CCV-F } \\
\text { CCV-R }\end{array}$ & $\begin{array}{l}\text { CTTGGTAATCGTGGTGCTAAT } \\
\text { TCAATCTGGTCGCCATCTTC }\end{array}$ & $\mathrm{N}$ & 530 & $\begin{array}{l}95^{\circ} \mathrm{C} \text { for } 5 \mathrm{~min} \text {, followed by } 30 \text { cycles at } 95^{\circ} \mathrm{C} \text { for } 30 \mathrm{~s} \text {, } \\
52^{\circ} \mathrm{C} \text { for } 30 \mathrm{~s} \text { and } 72^{\circ} \mathrm{C} \text { for } 40 \mathrm{~s} \text { and a final extension } \\
\text { step at } 72^{\circ} \mathrm{C} \text { for } 10 \mathrm{~min}\end{array}$ \\
\hline $\begin{array}{l}\text { CDV-F } \\
\text { CDV-R }\end{array}$ & $\begin{array}{l}\text { GAAGGGTCGAAAGCTCAAGG } \\
\text { ACACCAACTCCCATAGCATAAC }\end{array}$ & $\mathrm{N}$ & 617 & $\begin{array}{l}95^{\circ} \mathrm{C} \text { for } 5 \mathrm{~min} \text {, followed by } 30 \text { cycles at } 95^{\circ} \mathrm{C} \text { for } 30 \mathrm{~s} \text {, } \\
53^{\circ} \mathrm{C} \text { for } 30 \mathrm{~s} \text { and } 72^{\circ} \mathrm{C} \text { for } 40 \mathrm{~s} \text { and a final extension } \\
\text { step at } 72^{\circ} \mathrm{C} \text { for } 10 \mathrm{~min}\end{array}$ \\
\hline $\begin{array}{l}\text { CaAstV-F } \\
\text { CaAstV-R }\end{array}$ & $\begin{array}{l}\text { GTACTATACCRTCTGATTTAATT } \\
\text { AGACCAARGTGTCATAGTTCAG }\end{array}$ & ORF1b & 625 & $\begin{array}{l}95^{\circ} \mathrm{C} \text { for } 5 \mathrm{~min} \text {, followed by } 35 \text { cycles at } 95^{\circ} \mathrm{C} \text { for } 20 \mathrm{~s} \text {, } \\
58^{\circ} \mathrm{C} \text { for } 30 \mathrm{~s} \text { and } 72^{\circ} \mathrm{C} \text { for } 90 \mathrm{~s} \text { and a final extension } \\
\text { step at } 72^{\circ} \mathrm{C} \text { for } 5 \mathrm{~min}\end{array}$ \\
\hline
\end{tabular}

$\mathrm{CDV}$, canine distemper virus; $\mathrm{CaAstV}$, canine astrovirus; $\mathrm{CaKoV}$, canine kobuvirus; $\mathrm{CPV}$, canine parvovirus; $\mathrm{CCV}$, canine coronavirus 
no. NC001539) by PCR and for canine coronavirus (CCV, GenBank accession no. AB781800), canine distemper virus (CDV, GenBank accession no. JF965338), and canine astrovirus ( $\mathrm{CaAst} \mathrm{V}$, GenBank accession no. KX599391) by RT-PCR. The specific primers are listed in Table 1. The PCR and RT-PCR products were sequenced by Sangon Company.

\section{VP1 gene amplification}

A specific primer pair targeting $\mathrm{CaKoV} V P l$ was designed based on genome sequences from the GenBank database (accession nos. JQ911763 and MF062158). The PCR-amplified products were purified and cloned into the pMD-19T vector and confirmed by sequencing.

\section{Amplification of the complete CaKoV genome}

As shown in Table 2, eight pairs of specific primers were designed based on the sequences of the conserved regions of published CaKoV strains (accession nos. JQ911763 and MF062158). The PCR products were purified and cloned into the pMD-19T vector before sequencing.

\section{Sequence assembly and phylogenetic analysis}

The sequences were assembled using SeqMan software (DNASTAR, USA). The nt and aa sequences of the isolates were aligned with those obtained from the GenBank database (Table 3). The sequences were then aligned using the Clustal W method with MegAlign in DNASTAR software. To analyze evolutionary relationships, phylogenetic trees were constructed based on the Kimura 2-parameter model using the neighbor-joining method with 1000 bootstrap replicates with MEGA 6.0 software.

\section{Results}

\section{CaKoV detection and coinfection in clinical samples}

Fifty-seven fecal samples from dogs with diarrhea were collected to test for $\mathrm{CaKoV}$ infection. Among these, five samples were positive for $\mathrm{CaKoV}$, with an incidence rate of approximately 8.7\% (5/57) in Anhui Province from January 2018 to July 2019. All CaKoV-positive samples were subjected to further testing to detect other enteroviruses in order to identify possible coinfections. Interestingly, all five $\mathrm{CaKoV}$-positive samples were coinfected with CPV, and the

Table 2 Specific primers used for RT-PCR amplification and genomic sequencing

\begin{tabular}{|c|c|c|c|}
\hline Primer name & Nucleotide sequence $\left(5^{\prime}-3^{\prime}\right)$ & $\begin{array}{l}\text { Ampli- } \\
\text { con size } \\
\text { (bp) }\end{array}$ & Reaction conditions \\
\hline $\begin{array}{l}\text { CaKoV-1-F } \\
\text { CaKoV-1-R }\end{array}$ & $\begin{array}{l}\text { 1- TTTAAGTGTTGTGCCCAATCTCTTG } \\
\text { 689- CTTGGTAGTCAGTAGCAGTGATGTA }\end{array}$ & 689 & $\begin{array}{l}95^{\circ} \mathrm{C} \text { for } 5 \mathrm{~min} \text {, followed by } 30 \text { cycles at } 95^{\circ} \mathrm{C} \text { for } 30 \mathrm{~s}, 52^{\circ} \mathrm{C} \text { for } \\
30 \mathrm{~s} \text { and } 72^{\circ} \mathrm{C} \text { for } 40 \mathrm{~s} \text { and a final extension step at } 72^{\circ} \mathrm{C} \text { for } 10 \\
\text { min }\end{array}$ \\
\hline $\begin{array}{l}\text { CaKoV-2-F } \\
\text { CaKoV-2-R }\end{array}$ & $\begin{array}{l}\text { 600- TAATGGCAGGCAGAATGGAATCTCG } \\
\text { 1858- TGGGTACGCACGCACGAAGG }\end{array}$ & 1259 & $\begin{array}{l}95^{\circ} \mathrm{C} \text { for } 5 \mathrm{~min} \text {, followed by } 30 \text { cycles at } 95^{\circ} \mathrm{C} \text { for } 30 \mathrm{~s}, 54^{\circ} \mathrm{C} \text { for } \\
30 \mathrm{~s} \text { and } 72^{\circ} \mathrm{C} \text { for } 90 \mathrm{~s} \text { and a final extension step at } 72^{\circ} \mathrm{C} \text { for } 10 \\
\text { min }\end{array}$ \\
\hline $\begin{array}{l}\text { CaKoV-3-F } \\
\text { CaKoV-3-R }\end{array}$ & $\begin{array}{l}\text { 1745- AACCCTACATTCCCCATCTCATCAT } \\
\text { 2981- CATTCTCAATGTTGGCAGTGTCCTG }\end{array}$ & 1237 & $\begin{array}{l}95^{\circ} \mathrm{C} \text { for } 5 \mathrm{~min} \text {, followed by } 30 \text { cycles at } 95^{\circ} \mathrm{C} \text { for } 30 \mathrm{~s}, 53^{\circ} \mathrm{C} \text { for } \\
30 \mathrm{~s} \text { and } 72^{\circ} \mathrm{C} \text { for } 90 \mathrm{~s} \text { and a final extension step at } 72^{\circ} \mathrm{C} \text { for } 10 \\
\text { min }\end{array}$ \\
\hline $\begin{array}{l}\text { CaKoV-4-F } \\
\text { CaKoV-4-R }\end{array}$ & $\begin{array}{l}\text { 2900-TTCATGCAAAACCCCGCCCTCACCT } \\
\text { 3937- CTCCCACGGTTTGCCGAGTT }\end{array}$ & 1038 & $\begin{array}{l}95^{\circ} \mathrm{C} \text { for } 5 \mathrm{~min} \text {, followed by } 30 \text { cycles at } 95^{\circ} \mathrm{C} \text { for } 30 \mathrm{~s}, 53^{\circ} \mathrm{C} \text { for } \\
30 \mathrm{~s} \text { and } 72^{\circ} \mathrm{C} \text { for } 90 \mathrm{~s} \text { and a final extension step at } 72^{\circ} \mathrm{C} \text { for } 10 \\
\text { min }\end{array}$ \\
\hline $\begin{array}{l}\text { CaKoV-5-F } \\
\text { CaKoV-5-R }\end{array}$ & $\begin{array}{l}\text { 3803- GGAAGCACAAAGCAAATTTCCCTCT } \\
\text { 4784- GGGCCAATATGGAATCCGAGTAA }\end{array}$ & 982 & $\begin{array}{l}95^{\circ} \mathrm{C} \text { for } 5 \mathrm{~min} \text {, followed by } 30 \text { cycles at } 95^{\circ} \mathrm{C} \text { for } 30 \mathrm{~s}, 53^{\circ} \mathrm{C} \text { for } 30 \\
\mathrm{~s} \text { and } 72^{\circ} \mathrm{C} \text { for } 60 \mathrm{~s} \text { and a final extension step at } 72^{\circ} \mathrm{C} \text { for } 10 \mathrm{~min}\end{array}$ \\
\hline $\begin{array}{l}\text { CaKoV-6-F } \\
\text { CaKoV-6-R }\end{array}$ & $\begin{array}{l}\text { 4637- AATGTCGAGTGGATCGGAGAAACTG } \\
\text { 6649- GGGAGCCGGTTCCTTCTTGAT }\end{array}$ & 2013 & $\begin{array}{l}95^{\circ} \mathrm{C} \text { for } 5 \mathrm{~min} \text {, followed by } 30 \text { cycles at } 95^{\circ} \mathrm{C} \text { for } 30 \mathrm{~s}, 53^{\circ} \mathrm{C} \text { for } \\
30 \mathrm{~s} \text { and } 72^{\circ} \mathrm{C} \text { for } 150 \mathrm{~s} \text { and a final extension step at } 72^{\circ} \mathrm{C} \text { for } 10 \\
\text { min }\end{array}$ \\
\hline $\begin{array}{l}\text { CaKoV-7-F } \\
\text { CaKoV-7-R }\end{array}$ & $\begin{array}{l}\text { 6568- CGGTGTCAACATCAACCGGATGTCT } \\
\text { 7876- CCCAGACTTGAGGCACTGTTCG }\end{array}$ & 1309 & $\begin{array}{l}95^{\circ} \mathrm{C} \text { for } 5 \mathrm{~min} \text {, followed by } 30 \text { cycles at } 95^{\circ} \mathrm{C} \text { for } 30 \mathrm{~s}, 57^{\circ} \mathrm{C} \text { for } \\
30 \mathrm{~s} \text { and } 72^{\circ} \mathrm{C} \text { for } 90 \mathrm{~s} \text { and a final extension step at } 72^{\circ} \mathrm{C} \text { for } 10 \\
\text { min }\end{array}$ \\
\hline $\begin{array}{l}\text { CaKoV-8-F } \\
\text { CaKoV-8-R }\end{array}$ & $\begin{array}{l}\text { 7641- CGTCCACAATCTATGAAGTCACCT } \\
\text { 8216- TTTTTTTTTTTTTTTTTTTT } \\
\text { AAGAACAGTTAGAAAAGTT }\end{array}$ & 576 & $\begin{array}{l}95^{\circ} \mathrm{C} \text { for } 5 \mathrm{~min} \text {, followed by } 30 \text { cycles at } 95^{\circ} \mathrm{C} \text { for } 30 \mathrm{~s}, 57^{\circ} \mathrm{C} \text { for } \\
30 \mathrm{~s} \text { and } 72^{\circ} \mathrm{C} \text { for } 50 \mathrm{~s} \text { and a final extension step at } 72^{\circ} \mathrm{C} \text { for } 10 \\
\text { min }\end{array}$ \\
\hline
\end{tabular}


Table 3 Kobuvirus reference strains used in phylogenetic analysis

\begin{tabular}{lllll}
\hline Strain & Host species & Country & Gene & GenBank accession no. \\
\hline SMCD-59 & Canine & China & Whole genome + VP1 & MF062158 \\
CH-1 & Canine & China & Whole genome + VP1 & JQ911763 \\
US-PC0082 & Canine & USA & Whole genome + VP1 & JN088541 \\
UK003 & Canine & UK & Whole genome + VP1 & KC161964 \\
CaKoV-26 & Canine & Brazil & Whole genome + VP1 & MH747478 \\
12D049 & Canine & Korea & Whole genome + VP1 & KF924623 \\
WHJ-1 & Feline & China & Whole genome & MF598159 \\
12D240 & Feline & Korea & Whole genome & KJ958930 \\
FK-13 & Feline & Korea & Whole genome & KF831027 \\
TB3 & Sheep & Hungary & Whole genome & GU245693 \\
12Q108 & Caprine & Korea & Whole genome & NC023422 \\
EGY-1 & Bovine & Egypt & Whole genome & KY407744 \\
M-5-1 & Mouse & USA & Whole genome & NC015936 \\
HT9 & Marmot & China & Whole genome & KY855436 \\
SewKTM & Sewage & Nepal & Whole genome & JQ898342 \\
S-1-HUN & Swine & Hungary & Whole genome & EU787450 \\
XX & Swine & China & Whole genome & KC204684 \\
JS-01-CHN & Swine & China & Whole genome & KP144318 \\
\hline
\end{tabular}

sample with the AH-4 strain was coinfected with CaAstV (Table 4). There was no coinfection with CCV or CDV.

\section{VP1 gene sequencing and phylogenetic analysis}

The VPl sequences of the five CaKoV strains were 835-838 bp long and encoded polyproteins of 278-279 aa. Phylogenetic analysis demonstrated that the $\mathrm{CaKoV}$ isolates were divided into two separate groups: one including $\mathrm{CaKoV}$ isolates from China, and the other including $\mathrm{CaKoV}$ isolates from the USA, England, Korea, and Brazil. As shown in Fig. 1a, the VPl sequences of the five CaKoV strains detected in this study clustered into a single group, with $100 \%$ bootstrap support.

\section{Complete genome analysis of CaKoV strain AH-1/ CHN/2019}

In this study, the complete genome sequence of one $\mathrm{CaKoV}$ isolate was successfully amplified. The complete genome was $8223 \mathrm{nt}$ long; it contained an open reading frame (ORF) of $7335 \mathrm{nt}$ excluding the poly(A) tail, encoding a partial 5'-UTR of $601 \mathrm{nt}$ and a 248-nt 3'-UTR. The whole sequence was uploaded to the GenBank database and named "CaKoV AH-1/CHN/2019" (accession no. MN449341). The complete genome of CaKoV AH-1/ CHN/2019 has $20.3 \% \mathrm{~A}, 20.9 \% \mathrm{G}, 21.4 \% \mathrm{~T}$, and $37.4 \%$ $\mathrm{C}$ and thus has a high $\mathrm{G}+\mathrm{C}$ content $(58.29 \%)$, like other kobuviruses $(52 \%-59 \%)$.

The CaKoV AH-1/CHN/2019 strain showed 94.6\%-97\% nucleotide sequence identity and $93.1 \%-94 \%$ aa sequence identity with CaKoV strains CH-1 (JQ911763), SMCD59 (MF062158), CU101 (MK201777), and 12D049 (KF924623). We performed a phylogenetic analysis based on the complete genome of CaKoV AH-1/CHN/2019 and other representative kobuviruses (Fig. 1b).
Table 4 Coinfection status of CaKoV-positive samples

\begin{tabular}{lllllll}
\hline Strain & Feeding model & Diarrhea & CPV & CaAstV & CCV & CDV \\
\hline AH-1 & Domesticated & + & + & - & - & - \\
AH-2 & Domesticated & + & + & - & - & - \\
AH-3 & Domesticated & + & + & - & - & - \\
AH-4 & Domesticated & + & + & + & - & - \\
AH-5 & Domesticated & + & + & - & - & - \\
\hline
\end{tabular}

$\mathrm{CaKoV}$, canine kobuvirus; $\mathrm{CPV}$, canine parvovirus; $\mathrm{CCV}$, canine coronavirus; $\mathrm{CDV}$, canine distemper virus; $\mathrm{CaAstV}$, canine astrovirus 
Fig. 1 a. Neighbor-joining phylogenetic tree based on the VPI sequences of the $\mathrm{CaKoV}$ strains. Isolates from this study are indicated by black boxes. The tree was constructed using the neighbor-joining method with the Kimura 2-parameter model and 1000 bootstrap replicates using MEGA6.0 software. 1 b. Phylogenetic tree based on an alignment of the complete genome sequences of $\mathrm{CaKoV}$ and other members of the genus Kobuvirus. The tree was constructed using the neighborjoining method with the Kimura 2-parameter model and 1000 bootstrap replicates using MEGA6.0 software. Isolates from this study are indicated by black boxes
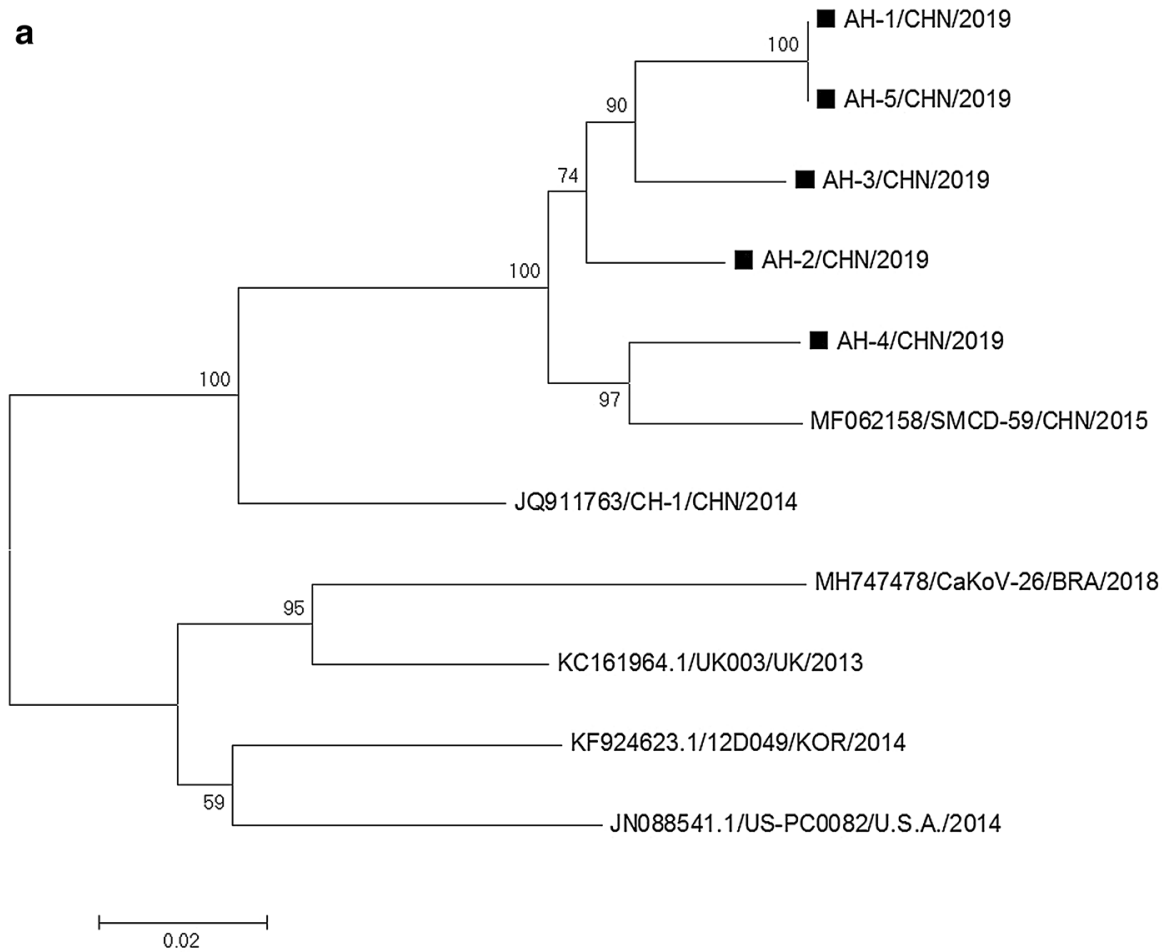

b

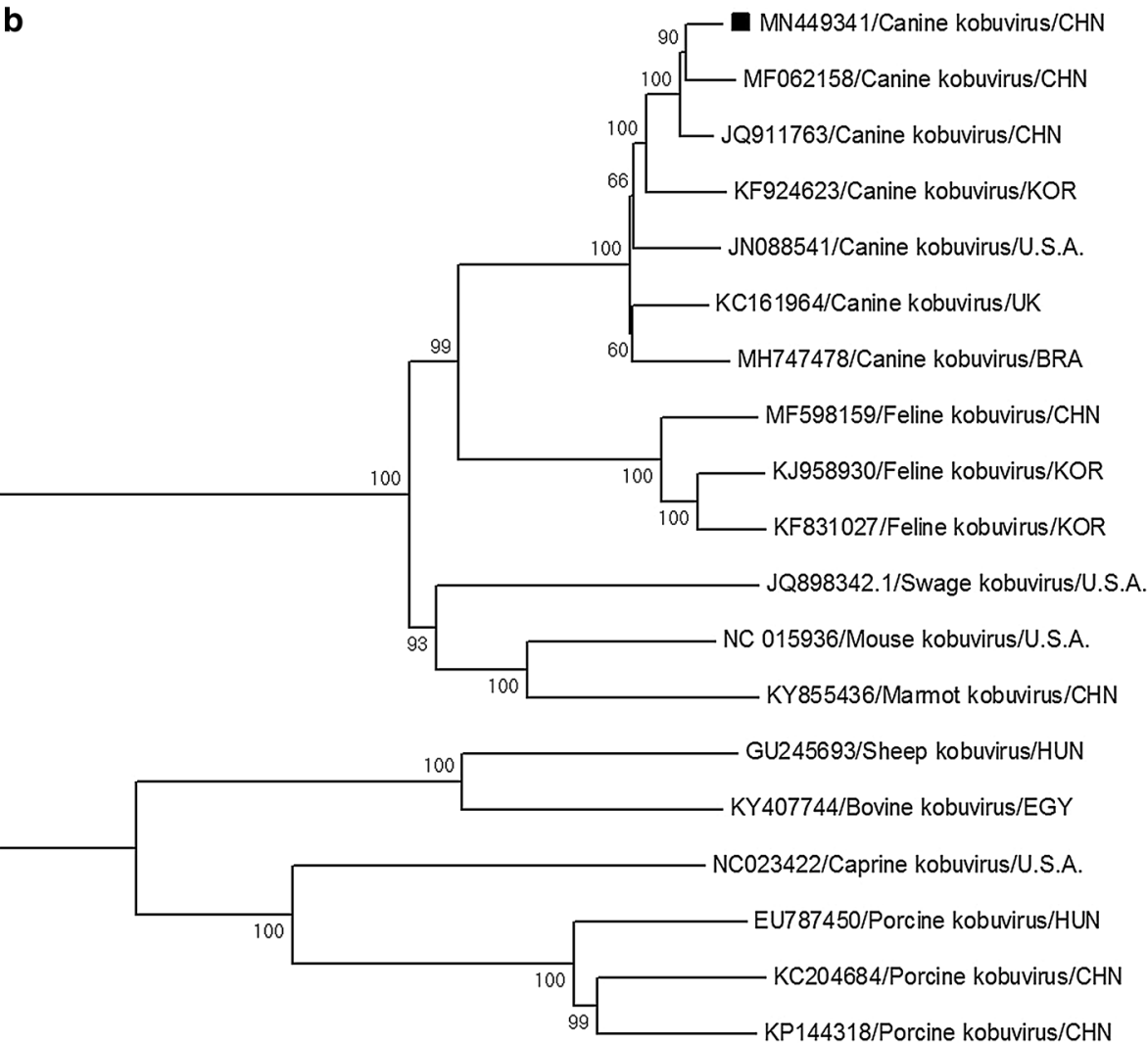




\section{Discussion}

Viruses are the main cause of gastroenteritis in animals, especially in puppies under 1 year of age [15]. The viruses frequently associated with gastroenteritis are CPV-2, CDV, $\mathrm{CCV}$, rotaviruses, adenoviruses, and some newly identified viruses such as $\mathrm{CaKoV}$ and $\mathrm{CaAstV}$ [11]. Animal kobuviruses have been detected in pigs, cattle, sheep, and dogs in several countries.

In this study, five strains of $\mathrm{CaKoV}$ were detected in fecal samples from 57 dogs with diarrhea in Anhui Province. The results showed that the $\mathrm{CaKoV}$ infection rate was approximately $8.7 \%$ (5/57). According to a previous study, the $\mathrm{CaKoV}$ infection rate in southwest and northeast China was $50.46 \%$ and $17.91 \%$, respectively $[10,12]$. Thus, the $\mathrm{CaKoV}$ infection rate in Anhui Province may be lower than that in southwest and northeast China. We are continuing to collect samples from animal hospitals and animal shelters in Anhui Province for further study. Furthermore, according to previous studies, enteroviruses are frequently found in coinfections with other pathogens. Therefore, we simultaneously tested for some common pathogens. It has been reported that the CPV coinfection rate ranges from $41.67 \%$ to $100 \%[10,13]$. Interestingly, in this study, all of the $\mathrm{CaKoV}$-positive samples showed the co-occurrence of CPV infection (Table 4), indicating the CPV co-infection rate in eastern China was higher than that in northeast and southwest China. Further study is required to identify synergy with parvoviruses $[10,12]$. Only one sample was coinfected with $\mathrm{CaAstV}$, and there was no coinfection with $\mathrm{CCV}$ or CDV. It has been reported that $\mathrm{CaKoV}$ can cause serious systemic infections [18]. Together, these findings imply that the high coinfection rate of $\mathrm{CaKoV}$ with other enteroviruses should be considered an important risk factor that could lead to gastroenteritis. The infection mechanism of $\mathrm{CaKoV}$ and the role of coinfection with other enteroviruses should be further investigated. We will expand the number and scope of samples collected in the future to compare diarrheic and asymptomatic infections.

The VP1 protein of aichivirus is the most exposed and immunodominant portion of the kobuvirus capsid, and it is the most variable structural protein $[5,17,21]$. Phylogenetic analyses of the VPl sequence and the complete genome sequence of $\mathrm{CaKoV}$ allowed us to obtain information on the genetic relationships among the identified strains and other $\mathrm{CaKoV}$ strains reported worldwide, as well as other members of the genus Kobuvirus [13]. The five amplified $V P 1$ sequences showed significant clustering and a high degree of similarity to previously reported Chinese strains. This result was consistent with that of a previous phylogenetic analysis based on VPI of strains from China [12]. In this study, compared with other published CaKoV VP1 aa sequences, the five $\mathrm{CaKoV}$ VP1 aa sequences contained substitutions. Whether these differences affect protein function still needs to be clarified. Notably, the phylogenetic analysis showed that the Chinese strains clustered separately from other published VP1 sequences of strains from Europe and South America, suggesting that the CaKoV strains from China may have a similar evolutionary background. In addition to this, we found that strains from Anhui and southwest China were more closely associated with strains from Asia, and according to a previous study, strains from northeast China showed similarity to strains from Europe, suggesting that there may be two different $\mathrm{CaKoV}$ lineages in mainland China.

To investigate the genetic characteristics of $\mathrm{CaKoV}$ strains circulating in dogs in Anhui Province, we successfully amplified the complete genome of one $\mathrm{CaKoV}$ strain, which was named CaKoV AH-1/CHN/2019. Our study is the first to report the complete genome sequence of a $\mathrm{CaKoV}$ strain from Anhui Province, and this will be helpful for further understanding $\mathrm{CaKoV}$ epidemiology in China. A phylogenetic analysis based on the complete genome sequence also indicated that the $\mathrm{CaKoV}$ strain was more closely related to strains from China than to those from Europe, Australia, and America. This is in agreement with previously published results $[10,12]$. Furthermore, a phylogenetic analysis of $\mathrm{CaKoV}$ and members of different kobuvirus species revealed that $\mathrm{CaKoV}$ AH-1/CHN/2019 was more closely related to feline kobuviruses than to sheep and bovine kobuviruses. One of the most likely reasons for this is that cats and dogs are often raised together in modern families; once a cat or dog is infected with a kobuvirus, cross-species cross-infection can easily occur. We will focus on this aspect in future research. The links between different kobuvirus strains need to be confirmed by extensive epidemiological surveys.

In conclusion, $\mathrm{CaKoV}$ showed widespread circulation in dogs with diarrhea in Anhui Province. The results of the present study provide phylogenetic information on the molecular epidemiology of $\mathrm{CaKoV}$ and indicate that the high coinfection rate of $\mathrm{CaKoV}$ and $\mathrm{CPV}$ deserves more attention.

Acknowledgements This work was supported financially by the Anhui Provincial Primary Research \& Development Plan (201904f06020030).

\section{Compliance with ethical standards}

Conflict of interest The authors declare that they have no conflict of interest.

\section{References}

1. Ambert-Balay K, Lorrot M, Bon F, Giraudon H, Kaplon J, Wolfer M, Lebon P, Gendrel D, Pothier P (2008) Prevalence and genetic 
diversity of Aichi virus strains in stool samples from community and hospitalized patients. J Clin Microbiol 46:1252-1258

2. Carmona-Vicente N, Buesa J, Brown PA, Merga JY, Darby AC, Stavisky J, Sadler L, Gaskell RM, Dawson S, Radford AD (2013) Phylogeny and prevalence of kobuviruses in dogs and cats in the UK. Vet Microbiol 164:246-252

3. Chang JT, Chen YS, Chen BC, Chao D, Chang TH (2013) Complete genome sequence of the first Aichi virus isolated in Taiwan. Genome Announc 1(1):e00107-12

4. Charoenkul K, Janetanakit T, Chaiyawong S, Bunpapong N, Boonyapisitsopa S, Tangwangvivat R, Amonsin A (2019) First detection and genetic characterization of canine Kobuvirus in domestic dogs in Thailand. BMC Vet Res 15:254

5. Chen L, Zhu L, Zhou YC, Xu ZW, Guo WZ, Yang WY (2013) Molecular and phylogenetic analysis of the porcine kobuvirus VP1 region using infected pigs from Sichuan Province, China. Virol J 10:281

6. Choi S, Lim SI, Kim YK, Cho YY, Song JY, An DJ (2014) Phylogenetic analysis of astrovirus and kobuvirus in Korean dogs. $\mathbf{J}$ Vet Med Sci 76:1141-1145

7. Di Martino B, Di Felice E, Ceci C, Di Profio F, Marsilio F (2013) Canine kobuviruses in diarrhoeic dogs in Italy. Vet Microbiol 166:246-249

8. Di Martino B, Di Profio F, Melegari I, Robetto S, Di Felice E, Orusa R, Marsilio F (2014) Molecular evidence of kobuviruses in free-ranging red foxes (Vulpes vulpes). Arch Virol 159:1803-1806

9. Khamrin P, Maneekarn N, Okitsu S, Ushijima H (2014) Epidemiology of human and animal kobuviruses. Virusdisease 25:195-200

10. Li C, Wei S, Guo D, Wang Z, Geng Y, Wang E, Zhao X, Su M, Wang X, Sun D (2016) Prevalence and phylogenetic analysis of canine kobuviruses in diarrhoetic dogs in northeast China. J Vet Med Sci 78:7-11

11. Li L, Pesavento PA, Shan T, Leutenegger CM, Wang C, Delwart E (2011) Viruses in diarrhoeic dogs include novel kobuviruses and sapoviruses. J Gen Virol 92:2534-2541

12. Li M, Yan N, Wang M, Zhang B, Yue H, Tang C (2018) Prevalence and genomic characteristics of canine kobuvirus in southwest China. Arch Virol 163:459-466
13. Miyabe FM, Ribeiro J, Alfieri AF, Alfieri AA (2019) Detection of canine kobuvirus RNA in diarrheic fecal samples of dogs with parvoviruses. Braz J Microbiol 50:871-874

14. Olarte-Castillo XA, Heeger F, Mazzoni CJ, Greenwood AD, Fyumagwa R, Moehlman PD, Hofer H, East ML (2015) Molecular characterization of canine kobuvirus in wild carnivores and the domestic dog in Africa. Virology 477:89-97

15. Ortega AF, Martinez-Castaneda JS, Bautista-Gomez LG, Munoz RF, Hernandez IQ (2017) Identification of co-infection by rotavirus and parvovirus in dogs with gastroenteritis in Mexico. Braz J Microbiol 48:769-773

16. Reuter G, Boldizsar A, Pankovics P (2009) Complete nucleotide and amino acid sequences and genetic organization of porcine kobuvirus, a member of a new species in the genus Kobuvirus, family Picornaviridae. Arch Virol 154:101-108

17. Reuter G, Boros A, Pankovics P (2011) Kobuviruses-a comprehensive review. Rev Med Virol 21:32-41

18. Ribeiro J, Headley SA, Diniz JA, Pereira AH, Lorenzetti E, Alfieri AA, Alfieri AF (2017) Extra-intestinal detection of canine kobuvirus in a puppy from Southern Brazil. Arch Virol 162:867-872

19. Soma T, Matsubayashi M, Sasai K (2016) Detection of kobuvirus RNA in Japanese domestic dogs. J Vet Med Sci 78:1731-1735

20. Yamashita T, Sakae K, Tsuzuki H, Suzuki Y, Ishikawa N, Takeda N, Miyamura T, Yamazaki S (1998) Complete nucleotide sequence and genetic organization of Aichi virus, a distinct member of the Picornaviridae associated with acute gastroenteritis in humans. J Virol 72:8408-8412

21. Yamashita T, Ito M, Kabashima Y, Tsuzuki H, Fujiura A, Sakae $\mathrm{K}$ (2003) Isolation and characterization of a new species of kobuvirus associated with cattle. J Gen Virol 84:3069-3077

Publisher's Note Springer Nature remains neutral with regard to jurisdictional claims in published maps and institutional affiliations. 